\title{
Does Conditionality Mitigate the Potential Negative Effect of Aid on Revenues?
}




\section{WP/16/142}

\section{IMF Working Paper}

\section{Does Conditionality Mitigate the Potential Negative Effect of Aid on Revenues?}

by Ernesto Crivelli and Sanjeev Gupta

I N T E R N A T I O N A L M O N E T A R Y F U N D 


\title{
IMF Working Paper
}

Fiscal Affairs Department

\section{Does Conditionality Mitigate the Potential Negative Effect of Aid on Revenues? ${ }^{1}$ Prepared by Ernesto Crivelli and Sanjeev Gupta}

July 2016

\section{This Working Paper should not be reported as representing the views of the IMF.} The views expressed in this Working Paper are those of the author(s) and do not necessarily represent those of the IMF or IMF policy. Working Papers describe research in progress by the author(s) and are published to elicit comments and to further debate.

\begin{abstract}
This paper assesses whether conditionality in IMF-supported programs has helped offset the potential negative effect of foreign aid on tax revenues. The analysis - carried out on panel data covering 1993-2012 for 111 low- and middle-income countries-shows that growing use of revenue conditionality by low-income countries partially offsets the depressing effect of foreign grants on tax revenue, particularly on taxes on goods and services. The impact of conditionality is strong in countries where aid dependence is high and where institutions are strong, suggesting that revenue conditionality cannot substitute for weak institutions in mitigating the negative effect of aid on tax revenue collection.

JEL Classification Numbers: C33; E62; F33; F35; H2

Keywords: Foreign aid; Tax revenue reform; structural conditionality

Author's E-Mail Address: ECrivelli@,imf.org; SGupta@imf.org

\footnotetext{
${ }^{1}$ This paper is appearing in a special issue of the Journal of Development Studies on Macroeconomic Perspectives of Aid: research methodology and policy frameworks. We would like to thank the Editors Tony Addison, Oliver Morrissey, and Finn Tarp, and two anonymous referees for excellent suggestions. We are grateful to Katherine Baer, Benedict Clements, Julio Escolano, Vitor Gaspar, Glenn Gottselig, Joao Jalles, Paulo Lopes, Giovanni Melina, Nicolas Mombrial, Abdelhak Senhadji, Mariusz Sumlinski, Philippe Wingender, and participants at an FAD seminar for many helpful suggestions and to Haoyu Wang for outstanding assistance with consolidating the data.
} 


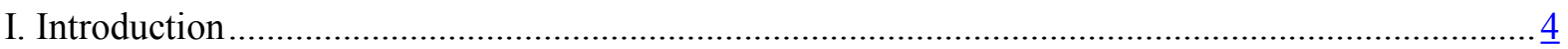

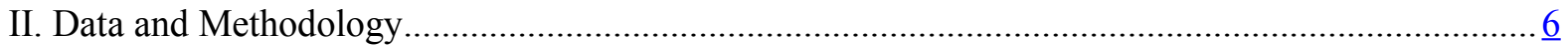

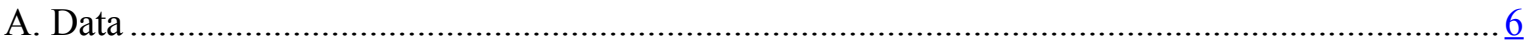

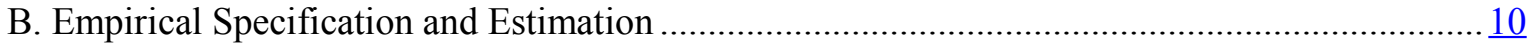

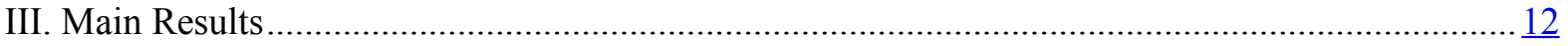

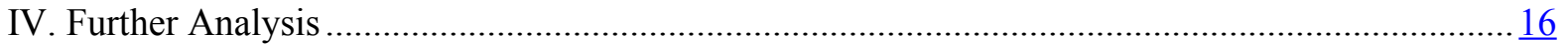

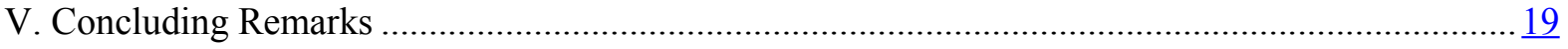

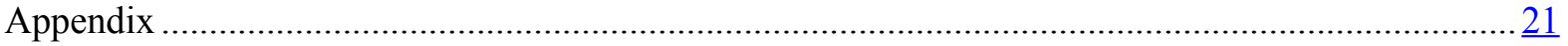

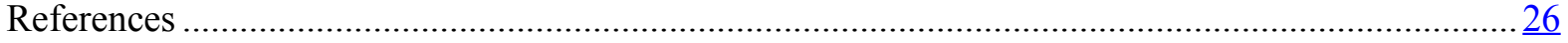

\section{Tables}

1. ODA Grants, Revenue Conditionality, and Total Tax Revenue ...............................................13

3. ODA Grants and Revenue Conditionality on Tax Revenue by level of Income ............................17

4. ODA Grants and Revenue Conditionality on Tax Revenue by level of ODA …........................... 18

5. ODA Grants and IMF Revenue Conditionality on Total Tax Revenue by ....................................19

\section{Figures}

1. Average Tax Revenue and ODA Grants, 1993-2012 ….......................................................... 7

2. IMF Technical Assistance (TA) in the Revenue Area …............................................................. $\underline{9}$

\section{Appendix Tables}

A1. Summary statistics.

A2. Result of Probit Regression to Generate Inverse Mills Ratio .................................................. 23

A3. Intensity of Revenue Conditionality (OLS and system-GMM) ............................................... 24 


\section{INTRODUCTION}

The effect of foreign aid on tax revenue collection continues to be widely debated. Aid is much more volatile and unpredictable than tax revenue, and the volatility of aid grows with the degree of aid dependence (Bulir and Hamann, 2001). This volatility has implications for macroeconomic stability in aid dependent countries (Hudson, 2015). Some scholars (Djankov et al., 2008) have argued that a growing dependence on aid can reduce incentives for governments to adopt good policies and maintain efficient institutions, such as an effective revenue administration and granting of widespread exemptions resulting in revenue losses. This is particularly relevant in countries where the share of aid in government budgets is relatively high. While aid in the form of grants was close to 3 percent of GDP, on average, in 2012 (about 20 percent of tax revenue), it averaged 5 percent of GDP among low-income countries (about 50 percent of tax revenue).

A number of papers (Ghura, 1998; Remmer, 2004; Gupta et al., 2004; Lee and Lee, 2014) have shown that foreign aid has a negative effect on domestic resource mobilization and the impact is significant when aid takes the form of grants. ${ }^{2}$ This result has been challenged by Clist and Morrissey (2011) and Carter (2013) who argue that the adverse effect of aid on domestic revenue effort disappears and becomes even positive for the last 15-20 years. More recently, studies using a comprehensive and disaggregated dataset, however, find that the negative relationship still holds for both total taxes and its constituents but appears to have weakened in relation to earlier studies (Thornton, 2013; Benedek et al., 2014). One possible explanation for the declining effect is the increased use of revenue conditionality in aid recipient countries, requiring these countries to implement revenue reforms in the context of program implementation. Crivelli and Gupta (2016), for instance, show that the use of revenue conditionality in IMF-supported programs indeed impacts positively on revenue performance. More specifically, in analyzing a panel of 37 sub-Saharan African countries during 2000-2008, Knoll (2011) finds that on-budget aid delivered under well-targeted conditionality successfully mitigates adverse fiscal incentives.

The purpose of this paper is to revisit the debate on the relationship between aid and tax revenue (and different components of tax revenue) by formally considering the impact of revenue conditionality in aid recipient countries. Earlier studies have used the volume of IMF loan disbursements to proxy for conditional aid (Montinola, 2010; Mosley, 2015) on the assumption that if IMF loans were disbursed, the recipient country must have met IMF conditionality. In general, donors tend to rely on the IMF to implement macroeconomic conditionality - including revenue conditionality. In this paper, we focus directly on revenue

\footnotetext{
${ }^{2}$ For a review of earlier empirical findings, as well as country studies see Gupta et al. (2004). A more recent survey of the empirical literature can be found in Morrissey (2015).
} 
conditionality that has taken the form of "structural benchmarks" in IMF programs. ${ }^{3}$ We take this conditionality as a proxy for all donor conditionality on the revenue side. In recent years, revenue conditionality in Fund programs has increased, reflecting growth in technical assistance in this area provided by the IMF. This technical assistance has provided recipient countries with options to strengthen their tax policy design and administration with the objective of broadening the tax base. ${ }^{4}$ Reflecting the implementation of tax reforms in the sample countries, the average tax-to-GDP ratio in these countries rose from 10.7 percent of GDP in 1993 to 17.9 percent of GDP in 2013.

To this end, we use a comprehensive panel dataset covering over 100 low- and middleincome countries during 1993-2012, a period over which IMF revenue conditionality data are available. Alternative estimation techniques are proposed to address the potential issue of endogeneity of aid, and sample selection bias associated with the likelihood of participating in an IMF program. To address recent concerns about potential weaknesses in the revenue datasets used in earlier studies, ${ }^{5}$ the model is tested on two alternative databases. Finally, we perform several robustness tests to account for a differentiated effect of aid - and the impact of revenue conditionality - on tax revenue. Our results corroborate earlier findings of a negative - albeit small — effect of foreign grants on tax revenue. Our findings also suggest that revenue conditionality has been effective in offsetting the potential negative effect of aid on tax revenue. This result holds in particular for taxes on goods and services. It also holds for countries otherwise suffering the most from the negative effect of aid on tax revenue, such as countries largely dependent on aid flows and middle-income countries.

The rest of this paper is structured as follows. In Section II, we describe the different datasets used in our analyses and present trends in tax revenue collection, foreign aid, and revenue conditionality in IMF programs. We then describe the empirical specification and estimation strategy. In Section III we present the main results on total tax revenue as well as on main taxes, whereas Section IV provides additional robustness analyses. Section V summarizes the results and discusses the policy implications.

\footnotetext{
${ }^{3}$ Conditionality can take different forms, including prior actions (PA), quantitative performance criteria (QPC), indicative targets (IT), or structural benchmarks (SB). Prior actions are measures that a country agrees to take before the IMF's Executive Board approves financing or completes a review. Quantitative performance criteria are specific and measurable conditions that have to be met to complete a review. Indicative targets are used to supplement QPCs for assessing programs. Structural benchmarks are reform measures that are important to achieve program goals and are intended to assess program implementation during a review.

${ }^{4}$ A sample of published technical assistance reports can be found at www.imf.org/external/ns/cs.aspx?id=299.

${ }^{5}$ See, Clist (2014) and Morrissey et al. (2014) that use the ICTD revenue dataset to revisit the aid-tax relationship.
} 


\section{Data ANd Methodology}

\section{A. Data}

The dataset comprises an unbalanced panel of 111 low- and middle-income countries ${ }^{6}$ for the period 1993-2012. Data on tax revenues are taken from two alternative sources. The first one is compiled by the IMF's Fiscal Affairs Department (FAD). For this database, data are drawn from three sources: the IMF's Government Finance Statistics (GFS), the IMF's World Economic Outlook(WEO), and the Organization for Economic Co-operation and Development (OECD)'s Revenue Statistics in Latin America. To ensure consistency, only one data source is used for a given tax series/country over the entire sample period. The second revenue database has been recently put together by the International Centre for Tax and Development (ICTD). In addition to the above mentioned sources, ${ }^{7}$ the ICTD database incorporates data extracted from IMF Article IV reports and statistical appendices in order to fill gaps in international datasets, such as by the IMF. By doing so, the ICTD database covers more countries (111 countries in our analysis as compared to 105 using the IMF database). Besides data on total tax revenue collection, the analysis in this paper uses data on taxes on goods and services (G\&S), income taxes (Income), and taxes on international transactions (Trade), all expressed relative to GDP. Both databases provide this level of data disaggregation. In addition, the ICTD database contains aggregates of direct and indirect tax revenues, also expressed in percent of GDP, which have been used for further robustness checks. Data on Official Development Assistance (ODA) in the form of grants were collected from the OECD/DAC. Full details of the dataset and summary statistics are provided in the Appendix.

Figure 1 displays the relationship between total tax revenue (including its main components) and aid during the period 1993-2012. The data plots suggest a negative association between ODA grants and total tax revenues, taxes on goods and services, as well as income taxes. ${ }^{8}$ However, ODA and trade taxes appear to be positively associated. Several studies have highlighted the possibility of differences in the taxation-aid relationship, depending on the type of tax (Gambaro et al., 2007; Carter, 2013). In general, as noted above, the negative association between ODA and tax revenue could be attributed to widespread tax exemptions. For taxes on goods and services, recent estimates (IMF, 2011) indicate a potential for raising

\footnotetext{
${ }^{6}$ Countries are grouped by income level following the World Bank classification. Full list of low- and middleincome countries, respectively, is shown in the Appendix.

${ }^{7}$ See, Prichard, Cobham, and Goodall (2014) for a detailed explanation of the construction of the ICTD revenue database.

${ }^{8}$ Same broad picture emerges when using data from ICTD. Benedek et al. (2014) show a similar picture for a longer time frame, 1980-2009, as well as pairwise correlations between tax revenue and total net ODA indicating a negative correlation for about 70 percent of the countries in their sample of 118 countries.
} 
additional VAT revenue in many developing countries by about 2 percent of GDP, on average. This is because of relatively low VAT efficiency (that is, the ratio of VAT revenue in percent of total consumption to the standard VAT rate) in many low- and low-middleincome countries, suggesting both poor VAT design and weak compliance. For trade taxes, the positive relationship with ODA has been explained by the fact that ODA facilitates higher imports that are not tax-exempt.

Figure 1. Average Tax Revenue and ODA Grants, 1993-2012 (percent of GDP)
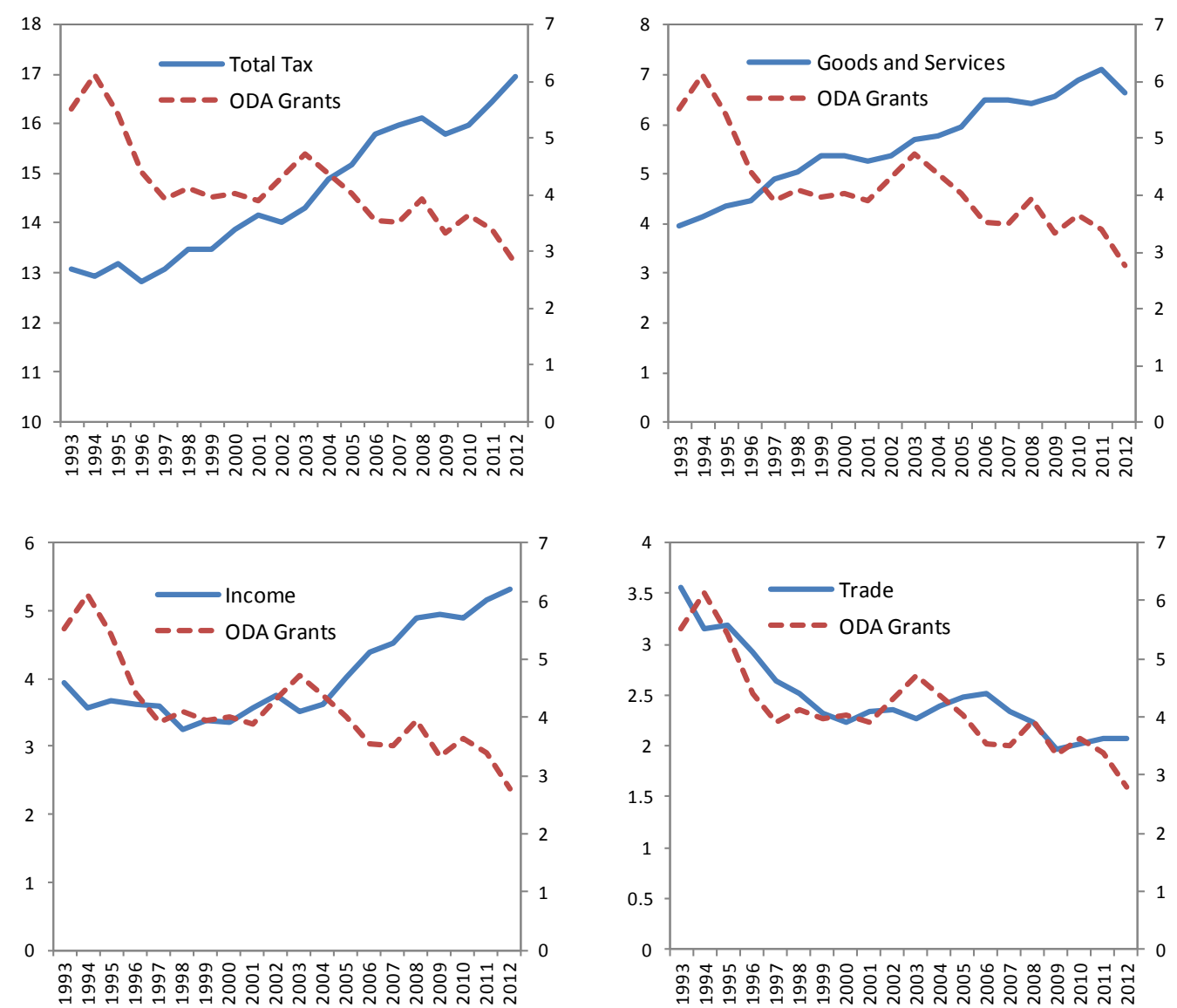

Note: Tax variables are shown in the left scale while ODA in the right scale.

Source: Authors' calculations; data from IMF's FAD revenue database and OECD DAC database.

Data on revenue conditionality included in IMF programs are taken from the IMF's Monitoring of Fund Arrangements (MONA) database, as explained in the Appendix. Revenue conditionality in the form of structural benchmarks may be specific (e.g., increasing the VAT rate to 18 percent) or general in nature (e.g., submitting a legislation to parliament for tax reform). At the same time, revenue conditionality can be related to tax policy or tax administration reform. The incidence of revenue conditionality in IMF programs is represented by binary variables (including for total tax, and for each of the main taxes) that 
equal one if a country in a given year had an IMF program with met $^{9}$ revenue conditionality and zero otherwise. The first lag of the revenue conditionality dummy is considered, to account for delayed reaction of tax revenue to the tax measure implied in the conditionality. This is particularly relevant where the revenue conditionality was added during a program review that took place late in the year. An alternative indicator is constructed using the number of revenue conditions as a share of the total number of conditions in a given country/year, which is aimed at better capturing the intensity of revenue conditionality.

Revenue conditionality has been embraced by many low- and middle-income countries. ${ }^{10}$ This reflects their desire to raise additional revenues to finance growing needs for infrastructure and social sectors. Since 1993, over 1,500 revenue conditions were met in the 441 newly approved IMF programs. On average, countries with IMF programs included revenue conditionality in at least 5 occasions over the sample period (there might be more than one revenue condition in a given year, for example applying to different taxes). Reliance on revenue conditionality has varied over time. While during the 1990s, middle-income countries made up the bulk of the IMF programs with revenue conditionality (about 60 percent), more recently low-income countries have increasingly included revenue conditionality (about 50 percent since 2006). This is reflected in the number of revenue conditions relative to the total conditions in IMF programs during this period. On average, revenue conditionality was close to 9 percent of the total among low-income countries, while only about 3.8 percent among middle-income countries. Since 2006 , however, revenue conditionality has increased to about 12 percent among low-income countries while remaining almost unchanged in middle-income countries. The latter reflects the growth in technical assistance in the revenue area provided to these countries by bilateral donors and international agencies (Figure 2). Finally, revenue conditionality has focused primarily on taxes on goods and services ( 56 percent), followed by conditionality on taxes on income (32 percent), and international transactions (12 percent).

\footnotetext{
${ }^{9}$ If the revenue conditionality was not met, the dummy variable takes the value zero, as it implies that the tax reform was not pursued and would then be equivalent to not having revenue conditionality in the first place.

${ }^{10}$ Crivelli and Gupta (2015) provide an extensive discussion on IMF program modalities as well as reliance on revenue conditionality over time, including on different taxes.
} 
Figure 2. IMF Technical Assistance (TA) in the Revenue Area

(TA Delivery in Staff Years and Percent of Total TA)

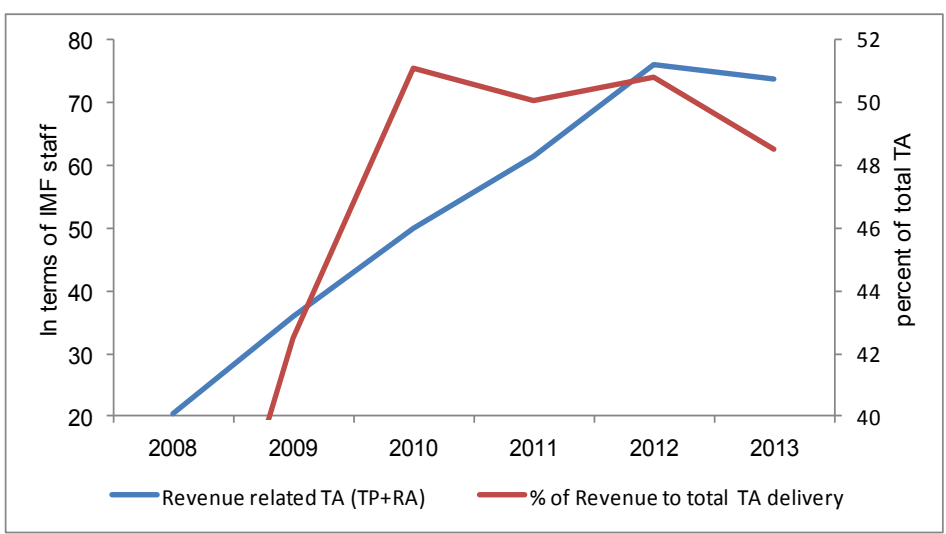

Source: Fiscal Affairs Department, IMF.

Note: TA in the revenue area includes tax policy (TP) and revenue administration (RA).

Crivelli and Gupta (2016) show that the use of revenue conditionality in IMF programs has been effective at improving revenue collection in low- and middle-income countries.

Figure 3 illustrates this by displaying tax-to-GDP ratios in countries where tax reform was supported by a period of at least two consecutive years of revenue conditionality. In more than 75 percent of such cases, the tax-to-GDP ratio increased as compared to the year prior to the inclusion of the revenue conditionality.

Figure 3. Tax Revenue and IMF Revenue Conditionality

(Before and after a period of consecutive conditionality, 1993-2013)

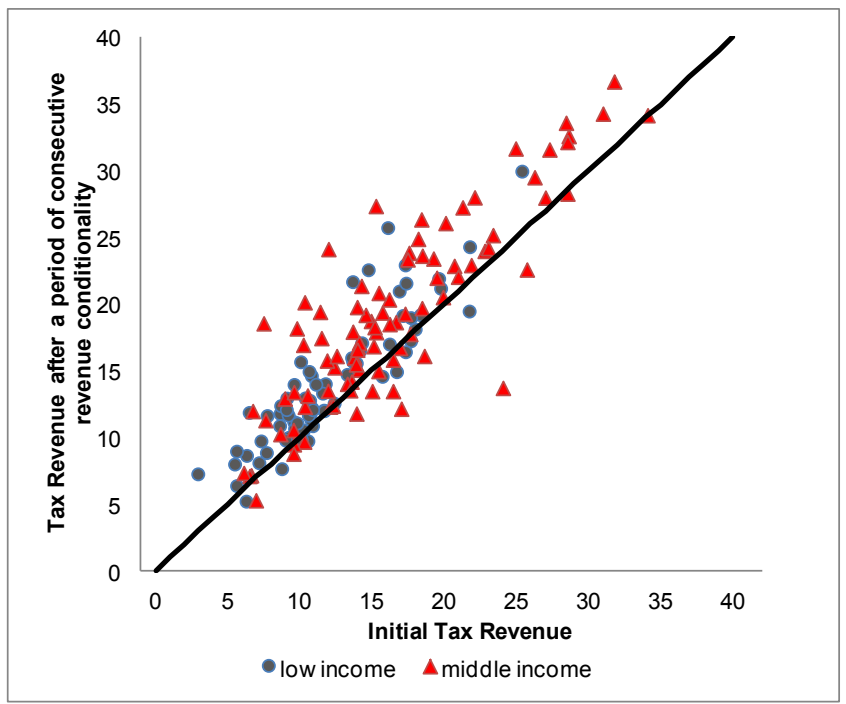

Source: Authors' calculations; data from GFS and MONA database, IMF. 


\section{B. Empirical Specification and Estimation}

The impact of aid on tax revenue in the presence of revenue conditionality in IMF-supported programs is explored by estimating equations of the form:

$$
T_{i t}=\beta_{1} T_{i t-1}+\beta_{2} O D A_{i t}+\beta_{3} D_{i t-1}+\beta_{4} O D A_{i t} \times D_{i t-1}+\zeta^{\prime} X_{i t}+\mu_{t}+\varepsilon_{i t}
$$

Eq. (1) is a semi-log specification ${ }^{11}$ where $T$ denotes tax revenues (in aggregate and by components) in country $i=1, \ldots, N$ at time $t=1, \ldots, L$, expressed relative to GDP, in logs; ODA grants, also expressed relative to GDP; and $D$ is a dummy variable for revenue conditionality in IMF programs (equal to 1 if an IMF-supported program with country $i$ includes revenue conditionality in year $t-1$ and 0 otherwise). $X$ is a vector of controls, and time-specific effects are also included. The lagged dependent variable allows for sluggish tax revenue response. The focus here is primarily on $\beta_{2}$ and $\beta_{4}$, that is the effect of ODA and the interaction between ODA and revenue conditionality in explaining tax revenue collection.

The control variables in $X$ have been commonly used in modeling tax revenues, and in the aid-tax literature. ${ }^{12}$ Per capita GDP, taken as a proxy for the overall development of the economy, is expected to show a positive correlation with revenue, reflecting a growing demand for public services with rising income per capita, and because of a higher degree of economic and institutional sophistication. The share of agriculture in value-added is expected to be negatively associated with revenue because agriculture is harder to tax. In contrast, the share of industry in value-added is expected to be positively associated with revenue. The degree of trade openness, measured as the sum of the shares of imports and exports in GDP, can present either sign. Rodrik (1998) argues that more open countries are vulnerable to risks and, given the need for social insurance, therefore tend to have bigger governments. Moreover, since trade taxes are easier to collect, especially in developing countries, a positive relationship between trade openness and revenues can be expected. However, higher trade openness could be the result of trade liberalization through tariff reductions, thus having a negative impact on revenue. Finally inflation, which may have revenue effects through both unindexed tax systems and the generation of seigniorage. ${ }^{13}$

\footnotetext{
${ }^{11}$ Gujarati and Porter (2009) suggest that the log transformation may be of advantage since it may reduce the incidence of heteroskedasticity and skewness of the data. Auriol and Warlters (2005) suggest that the log transformation may help ensure that out-of-sample fitted values of the tax-to-GDP ratio lie in the $0-100 \%$ range.

${ }^{12}$ For a review, see Baunsgaard and Keen (2010), Benedek et al. (2014), and Clist (2014).

${ }^{13}$ Results do not differ qualitatively or quantitatively by omitting inflation, as for example, in Clist (2014). Similarly, results are robust to considering exports and imports, separately, in percent of GDP, as opposed to including trade openness.
} 
Of concern in estimating Eq. (1) is the treatment of potential endogeneity of aid and tax revenue, as well as of IMF revenue conditionality and tax revenue. For the first, countries with the lowest tax-to-GDP ratio are generally also the largest aid recipients. For the second, IMF loans tend to be extended in response to economic imbalances (Conway, 2003). As such, countries with a low tax-to-GDP ratio-reflecting the underlying macroeconomic and structural weaknesses - may need to request IMF support to strengthen their fiscal position. Both cases create potential problems of reverse causality. Also of concern in the literature on the macroeconomic effect of IMF-supported programs is the possibility of sample selection bias associated with participation in an IMF-supported program. Countries that have an IMFsupported program may not be directly comparable to those without one because the former must address macroeconomic imbalances that will influence fiscal policy and the ability of the government to collect taxes, thus creating a potential selection bias problem.

To account for the selection-bias problem, we follow Barro and Lee (2005) in identifying suitable instruments to isolate the effects of IMF loan programs on tax revenue. To do so they apply Heckman's $(1976,1979)$ proposed two-stage estimation procedure which implies adding as a control variable, the so-called inverse Mills ratio, which is derived from a probit regression of the IMF program on three variables: international reserves in months of imports, the bilateral exchange rate to US dollar, and the overall fiscal balance (all of them are lagged by one period). These instruments, while likely correlated with the IMF program variable, are less likely to be directly correlated with tax revenue. ${ }^{14}$ While our identification strategy is commonly used in the literature to address potential endogeneity and selection bias in the IMF program variable, such methodology implies a number of exclusionary restrictions for estimation of an IMF participation equation that clearly depends on the appropriate choice of instruments. These instruments may be correlated with other variables (besides tax revenue) that could ultimately be correlated with the dependent variable, other than via their impact on IMF conditions. As a result, the exclusion restriction may be violated, and the estimation strategy potentially biased.

\footnotetext{
${ }^{14}$ The probit regression for the probability of a country to have an IMF program (Appendix Table A2) confirms the validity of the chosen instruments. Alternatively, other economic and political variables as in Moser and Sturm (2011) and Crivelli and Gupta (2015) were considered without significant differences in the results.
} 


\section{Main Results}

For the baseline results, Eq. (1) is estimated for total tax revenue (and components) with a simple specification using ordinary least squares with time fixed effects (OLS). Table 1 reports the results for total tax revenue, using the two revenue databases. For robustness, results are also presented including the Inverse-Mills ratio as an additional control variable as explained above. ${ }^{15}$

Turning first to the control variables, the overall level of development, proxied by GDP per capita, is, when significant, positively related to tax revenue; with the same result found for trade openness. The level of inflation is also found significant in explaining tax revenue collection; presenting a negative sign in some specifications, possibly reflecting non linearity, that is a high level of inflation negatively affecting revenue collection.

Attention focuses first on the impact of aid on tax revenue. Results are shown in Column 1 (IMF database) and Column 4 (ICTD database). Results largely confirm earlier findings in the literature of a negative association between aid in the form of grants and tax revenue (Gupta et al., 2004; Thornton, 2013; Benedek et al., 2014) and appear to be robust to the use of different tax revenue databases.

The main difference with earlier findings in the literature is in the size of the estimated effect which indicates a weakening impact of grants on incentives to mobilize revenue collection. The estimated coefficients in Table 1 imply an offsetting effect of about 0.05 percentage points of GDP for each additional percentage point of GDP in ODA grants for the recent period 1993-2012, when using OLS. ${ }^{16}$ This compares to about 0.10 percentage points of GDP in Benedek et al. (2014) for the period 1980-2009. Similarly, results using systemGMM (Appendix Table A3) suggest a smaller estimated effect of about 0.17 percentage points of GDP compared to that obtained in Benedek et al. (2014) of about 0.24 percentage points of GDP. As suggested also in Benedek et al. (2014), this weakening effect over time could be related to low-income countries increasing their reliance on revenue-related conditionality to deal with the potential negative consequences of ODA on revenues.

As a result, interest centers on the extent to which IMF's revenue conditionality affects the aid-tax revenue relationship. To address this formally in the empirical analysis, the ODA

\footnotetext{
${ }^{15}$ For further robustness, Appendix Table A3 presents additional results using an alternative variable to capture the intensity of revenue conditionality, as well as an alternative estimation methodology using a system generalized method of moments (GMM) that can be better suited to address possible endogeneity.

${ }^{16}$ Estimates are based on the regression coefficients reported in Table 1 (Column 3) and the average value of total tax revenues (about 16.4 percent of GDP). Recall we have a semilog regression of the form $\ln (Y)=\beta_{1}+$ $\beta_{2} X$, where the dependent variable $\mathrm{Y}$ (revenue ratio) is expressed in logs, whereas the explanatory variable $\mathrm{X}$ (ODA grants) is expressed as a ratio to GDP. Thus, the slope is equal to $\beta_{2} Y$.
} 
grants variable is interacted with the revenue conditionality dummy. Results are presented in Table 1, Column 2 (FAD database) and Column 5 (ICTD database). The estimated coefficient for the interaction between ODA and the revenue conditionality variable is positively and statistically significantly correlated with revenue collection. Again here, results are almost identical for alternative tax revenue databases. The results are robust to potential endogeneity and selection bias problems that are addressed in Table 1, Columns 3 and 6 by including the Inverse-Mills ratio as an additional control variable as explained above. The estimated coefficient for the interacted term is positively correlated with revenue, and with higher significance.

Table 1. ODA Grants, Revenue Conditionality, and Total Tax Revenue

\begin{tabular}{|c|c|c|c|c|c|c|}
\hline & (1) & (2) & (3) & (4) & (5) & (6) \\
\hline & \multicolumn{3}{|c|}{ OLS-IMF } & \multicolumn{3}{|c|}{ OLS-ICTD } \\
\hline Tax, lagged & $\begin{array}{c}0.9283 * * * \\
(0.0077)\end{array}$ & $\begin{array}{c}0.9311^{* * * *} \\
(0.0077)\end{array}$ & $\begin{array}{c}0.9461 * * * \\
(0.0082)\end{array}$ & $\begin{array}{c}0.9269^{* * *} \\
(0.0079)\end{array}$ & $\begin{array}{c}0.9281 * * * \\
(0.0081)\end{array}$ & $\begin{array}{c}0.9505^{* * *} \\
(0.0083)\end{array}$ \\
\hline ODA grants & $\begin{array}{c}-0.0013 * * \\
(0.0006)\end{array}$ & $\begin{array}{c}-0.0012 * * \\
(0.0006)\end{array}$ & $\begin{array}{c}-0.0028 * * * \\
(0.0008)\end{array}$ & $\begin{array}{l}-0.0009^{*} \\
(0.0005)\end{array}$ & $\begin{array}{c}-0.0011 * * \\
(0.0006)\end{array}$ & $\begin{array}{c}-0.0019 * * * \\
(0.0008)\end{array}$ \\
\hline IMF conditionality & & $\begin{array}{c}0.0041 \\
(0.0076)\end{array}$ & $\begin{array}{c}0.0019 \\
(0.0075)\end{array}$ & & $\begin{array}{c}0.0085 \\
(0.0072)\end{array}$ & $\begin{array}{c}0.0048 \\
(0.0073)\end{array}$ \\
\hline $\begin{array}{l}\text { ODA grants } x \\
\text { conditionality }\end{array}$ & & $\begin{array}{l}0.0018^{*} \\
(0.0011)\end{array}$ & $\begin{array}{c}0.0029 * * * \\
(0.0012)\end{array}$ & & $\begin{array}{l}0.0004^{*} \\
(0.0010)\end{array}$ & $\begin{array}{l}0.0024 * * \\
(0.0011)\end{array}$ \\
\hline Trade openness & $\begin{array}{c}0.0358 * * * \\
(0.0087)\end{array}$ & $\begin{array}{c}0.0325 * * * \\
(0.0087)\end{array}$ & $\begin{array}{c}0.0273 * * * \\
(0.0086)\end{array}$ & $\begin{array}{l}0.0133^{*} \\
(0.0080)\end{array}$ & $\begin{array}{l}0.0133^{*} \\
(0.0082)\end{array}$ & $\begin{array}{c}0.0081 \\
(0.0083)\end{array}$ \\
\hline Inflation & $\begin{array}{c}0.09126^{* *} \\
(0.0399)\end{array}$ & $\begin{array}{c}0.1682 * * * \\
(0.0514)\end{array}$ & $\begin{array}{c}-0.6557^{* *} \\
(0.2858)\end{array}$ & $\begin{array}{c}-0.0116^{* * * *} \\
(0.0045)\end{array}$ & $\begin{array}{c}-0.0120 * * * \\
(0.0045)\end{array}$ & $\begin{array}{l}-0.1744 \\
(0.2672)\end{array}$ \\
\hline $\begin{array}{l}\text { GDP per capita } \\
(\log )\end{array}$ & $\begin{array}{l}0.0351^{*} \\
(0.0289)\end{array}$ & $\begin{array}{l}0.0714^{*} \\
(0.0590)\end{array}$ & $\begin{array}{c}0.0065 \\
(0.0621)\end{array}$ & $\begin{array}{c}0.0174 \\
(0.0516)\end{array}$ & $\begin{array}{c}0.0275 \\
(0.0530)\end{array}$ & $\begin{array}{l}-0.0393 \\
(0.0586)\end{array}$ \\
\hline Agriculture & $\begin{array}{c}0.0218 \\
(0.0420)\end{array}$ & $\begin{array}{c}0.0283 \\
(0.0418)\end{array}$ & $\begin{array}{c}0.0270 \\
(0.0434)\end{array}$ & $\begin{array}{l}-0.0477 \\
(0.0380)\end{array}$ & $\begin{array}{l}-0.0409 \\
(0.0392)\end{array}$ & $\begin{array}{l}-0.0581 \\
(0.0433)\end{array}$ \\
\hline Industry & $\begin{array}{l}-0.0369 \\
(0.0282)\end{array}$ & $\begin{array}{l}-0.0389 \\
(0.0279)\end{array}$ & $\begin{array}{l}-0.0293 \\
(0.0278)\end{array}$ & $\begin{array}{c}-0.1424 * * \\
(0.0278)\end{array}$ & $\begin{array}{c}-0.1445^{* *} \\
(0.0283)\end{array}$ & $\begin{array}{c}-0.1134 * * * \\
(0.0282)\end{array}$ \\
\hline Constant & $\begin{array}{l}0.1237 * * \\
(0.0620)\end{array}$ & $\begin{array}{c}0.1239 \\
(0.1293)\end{array}$ & $\begin{array}{l}0.1315 * * \\
(0.0674)\end{array}$ & $\begin{array}{c}0.2165^{* * * *} \\
(0.0570)\end{array}$ & $\begin{array}{c}0.2865^{* *} \\
(0.1226)\end{array}$ & $\begin{array}{c}0.1961^{* * *} \\
(0.0670)\end{array}$ \\
\hline Inverse Mills ratio & & & $\begin{array}{c}0.0065 \\
(0.0110)\end{array}$ & & & $\begin{array}{c}0.0123 \\
(0.0114)\end{array}$ \\
\hline Adjusted R2 & 0.927 & 0.930 & 0.935 & 0.934 & 0.933 & 0.944 \\
\hline F-statistic & 802.5 & 951.3 & 708.0 & 989.9 & 864.01 & 829.9 \\
\hline P-value & 0.000 & 0.000 & 0.000 & 0.000 & 0.000 & 0.000 \\
\hline Observations & 1622 & 1578 & 1375 & 1663 & 1589 & 1258 \\
\hline $\begin{array}{l}\text { Number of } \\
\text { countries }\end{array}$ & 105 & 105 & 100 & 111 & 111 & 104 \\
\hline
\end{tabular}

Notes:

Dependent variable is the log of total tax revenue, relative to GDP. Full set of year dummies in all regressions. Standard errors, in parenthesis; $* * *(* *, *)$ indicate significance at $1(5,10)$ percent.

While the above result suggests that indeed revenue conditionality in IMF programs has helped offset the negative effect of aid on tax revenue collection, it needs to be recognized 
that donor aid also comes with conditionality (Knoll, 2011), including on tax-related measures. Thus, our results may be capturing the effect of aid conditionality more generally to the extent revenue conditionality in IMF programs coincided with general donor conditionality. In this light, we interpret our results more broadly as indicating that conditionality in general (and on revenues in particular) plays a role in mitigating the offsetting effect of aid on tax revenue collection.

Appendix Table A3 presents results when using an alternative conditionality variable that better captures the intensity of conditionality. As defined in Section II, this variable is constructed using the number of revenue conditions as a share of the total number of conditions in IMF programs for each country/year. With this alternative variable, results remain qualitatively identical and with similar estimated coefficients as in Table 1. Results are also qualitatively similar when using lags of 5-year averages of the explanatory variables, allowing a much smoother reaction of tax revenue collection to ODA and conditionality, while addressing potential double causality concerns. Results are presented in Appendix Table A4. ${ }^{17}$

We now turn to the impact of aid on disaggregated taxes, in particular once revenue conditionality is considered. To empirically test for a differential relationship between aid and taxes, we focus on taxes on goods and services, income taxes, and taxes on international transactions. Results using OLS are presented in Table 2. Panel A is based on the IMF's revenue database, and Panel B results rely on the ICTD's revenue dataset. The full set of control variables and year dummies are also included in the regressions.

Results for the aid-tax relationship are shown in Table 2, Columns 1, 3, and 5, for taxes on goods and services, income, and trade, respectively. ${ }^{18}$ As in previous findings in the literature, we find a strong (negative and significant) offsetting effect of aid on taxes on goods and services (of which Benedek et al. (2014) had focused on value-added and excise taxes separately). The estimated coefficient in Column 1, suggest an offsetting impact of 0.05 percentage point of GDP on taxes on goods and services for each additional percentage point of GDP in aid grants. Also as in previous findings, we do not find any significant impact of aid on taxes on income and trade. Results for the interaction of ODA with IMF's revenue conditionality in Columns 2, 4, and 6 suggest that revenue conditionality seem to have helped mitigate the effect of aid on revenues from taxes on goods and services, with a positive and statistically significant coefficient when using the IMF database.

\footnotetext{
${ }^{17}$ Results are also robust to alternative lag structures, to also using 5-year averages of the dependent variable, and to alternative estimation methods such as OLS with country fixed effects (OLS-FE) or system-GMM. These are not reported to save space.

${ }^{18}$ Similar results are obtained for additional tax aggregates provided in the ICTD dataset, namely for Indirect and Direct taxes, respectively. These results are not reported to save space.
} 
Table 2. ODA Grants and Revenue Conditionality on Different Taxes

\begin{tabular}{|c|c|c|c|c|c|c|}
\hline & (1) & (2) & (3) & (4) & (5) & (6) \\
\hline & \multicolumn{2}{|c|}{ G\&S } & \multicolumn{2}{|c|}{ Income } & \multicolumn{2}{|c|}{ Trade } \\
\hline Tax, lagged & $\begin{array}{c}0.9077 * * * \\
(0.0083)\end{array}$ & $\begin{array}{c}0.9164 * * * \\
(0.0095)\end{array}$ & $\begin{array}{c}0.8927 * * * \\
(0.0110)\end{array}$ & $\begin{array}{c}0.9101 * * * \\
(0.0113)\end{array}$ & $\begin{array}{c}0.9602 * * * \\
(0.0094)\end{array}$ & $\begin{array}{c}0.9690 * * * \\
(0.0095)\end{array}$ \\
\hline ODA grants & $\begin{array}{c}-0.0078 * * * \\
(0.0030)\end{array}$ & $\begin{array}{c}-0.0039 * * \\
(0.0018)\end{array}$ & $\begin{array}{c}0.0025 \\
(0.0018)\end{array}$ & $\begin{array}{c}0.0015 \\
(0.0028)\end{array}$ & $\begin{array}{c}0.0002 \\
(0.0020)\end{array}$ & $\begin{array}{l}-0.0008 \\
(0.0029)\end{array}$ \\
\hline IMF conditionality & & $\begin{array}{c}0.0469 * * * \\
(0.0143)\end{array}$ & & $\begin{array}{c}0.0102 \\
(0.0215)\end{array}$ & & $\begin{array}{l}-0.0272 \\
(0.0255)\end{array}$ \\
\hline $\begin{array}{l}\text { ODA grants } \mathrm{x} \\
\text { conditionality }\end{array}$ & & $\begin{array}{l}0.0035^{*} \\
(0.0022)\end{array}$ & & $\begin{array}{l}-0.0012 \\
(0.0040)\end{array}$ & & $\begin{array}{c}0.0028 \\
(0.0043)\end{array}$ \\
\hline Adjusted R2 & 0.904 & 0.906 & 0.865 & 0.887 & 0.926 & 0.944 \\
\hline F-statistic & 586.7 & 434.3 & 326.8 & 301.6 & 554.0 & 544.5 \\
\hline P-value & 0.000 & 0.000 & 0.000 & 0.000 & 0.000 & 0.000 \\
\hline Observations & 1606 & 1259 & 1316 & 1070 & 1141 & 899 \\
\hline $\begin{array}{l}\text { Number of } \\
\text { countries }\end{array}$ & 103 & 98 & 97 & 91 & 89 & 82 \\
\hline
\end{tabular}

\section{B) $O L S-I C T D$}

\begin{tabular}{|c|c|c|c|c|c|c|}
\hline Tax, lagged & $\begin{array}{c}0.9137 * * * \\
(0.0087)\end{array}$ & $\begin{array}{c}0.9162 * * * \\
(0.0088)\end{array}$ & $\begin{array}{c}0.9207 * * * \\
(0.0078)\end{array}$ & $\begin{array}{c}0.9320 * * * \\
(0.0084)\end{array}$ & $\begin{array}{c}0.9575 * * * \\
(0.0075)\end{array}$ & $\begin{array}{c}0.9673 * * * \\
(0.0083)\end{array}$ \\
\hline ODA grants & $\begin{array}{c}-0.0080^{* *} \\
(0.0011)\end{array}$ & $\begin{array}{l}-0.0012 \\
(0.0011)\end{array}$ & $\begin{array}{l}-0.0011 \\
(0.0010)\end{array}$ & $\begin{array}{l}-0.0006 \\
(0.0013)\end{array}$ & $\begin{array}{l}-0.0013 \\
(0.0012)\end{array}$ & $\begin{array}{l}-0.0023 \\
(0.0018)\end{array}$ \\
\hline IMF conditionality & & $\begin{array}{c}0.0309 * * \\
(0.0139)\end{array}$ & & $\begin{array}{l}-0.0018 \\
(0.0141)\end{array}$ & & $\begin{array}{l}-0.0172 \\
(0.0180)\end{array}$ \\
\hline $\begin{array}{l}\text { ODA grants } \mathrm{x} \\
\text { conditionality }\end{array}$ & & $\begin{array}{c}0.0012 \\
(0.0018)\end{array}$ & & $\begin{array}{c}0.0011 \\
(0.0019)\end{array}$ & & $\begin{array}{c}0.0035 \\
(0.0024)\end{array}$ \\
\hline Adjusted R2 & 0.909 & 0.912 & 0.925 & 0.936 & 0.940 & 0.948 \\
\hline F-statistic & 619.1 & 567.6 & 720.4 & 586.3 & 967.1 & 762.9 \\
\hline P-value & 0.000 & 0.000 & 0.000 & 0.000 & 0.000 & 0.000 \\
\hline Observations & 1477 & 1411 & 1398 & 1028 & 1471 & 1068 \\
\hline $\begin{array}{l}\text { Number of } \\
\text { countries }\end{array}$ & 109 & 101 & 108 & 99 & 107 & 99 \\
\hline
\end{tabular}

\section{Notes:}

a) Dependent variable is the log of tax revenue from goods and services, income tax, and taxes on international transactions, relative to GDP, respectively. Full set of year dummies and control variables in all regressions. Standard errors, in parenthesis; $* * *(* *, *)$ indicate significance at $1(5,10)$ percent.

b) Columns 2/4/6 include Inverse Mills ratio as additional control. 


\section{FURTher ANALYSIS}

This section intends to provide further robustness to the results presented in Section III by testing whether the effect of aid - and the impact of revenue conditionality — on total tax revenue is different between low- and middle-income countries. It also analyses whether the results are influenced by a greater reliance on aid by a country, and by the strength of institutions as proxied by the level of perceived corruption. For this purpose, OLS results are presented, for the IMF's revenue database. ${ }^{19}$ For all three robustness tests, we follow the same presentation as in the previous sections, namely presenting the impact of aid on revenue (Column 1), and the impact of revenue conditionality on the effect of aid on tax (Column 2), as well as the latter also including the Inverse-Mills ratio (Column 3) as additional control.

Table 3 presents the results for low- and middle-income countries. The differential effect of aid on tax revenue collection is investigated by interacting the ODA variable with a dummy variable for low-income countries (Column 1). The effect of aid on tax revenue collection among middle-income countries, as measured by the coefficient of the ODA variable without interaction, is negative and statistically significant as in Table 1. For low-income countries, however, the impact of aid on tax revenue is close to zero. The size of the interacted coefficient is roughly of the same magnitude (but opposite in sign) as for middle-income countries and also highly significant. This lower offsetting effect of aid on revenue could be explained by a larger and increasing intensity of revenue conditionality (possibly also associated with aid delivery) among low-income countries as explained in Section II. Turning to the impact of revenue conditionality on the offsetting effect of aid on revenue (Columns 2), the estimated coefficient for the interaction between ODA and the revenue conditionality variable is positively and statistically significantly correlated with revenue collection, suggesting also here that revenue conditionality has helped compensate the negative effect of aid on tax revenue. This latter effect appears to be similar among both lowand middle-income countries, as the interacted term with the dummy for low-income countries is not statistically significant. The same result is obtained in Column 3 once the Inverse-Mills ratio is included as additional control variable.

\footnotetext{
${ }^{19}$ Additional results, using OLS-FE or system-GMM, and using the ICTD database are qualitatively very similar and are thus not reported to save space.
} 
Table 3. ODA Grants and Revenue Conditionality on Tax Revenue by level of Income

\begin{tabular}{lccc}
\hline & $(1)$ & $(2)$ & $(3)$ \\
\hline Tax, lagged & $0.9285^{* * *}$ & $0.9311^{* * *}$ & $0.9469^{* * *}$ \\
ODA grants & $(0.0077)$ & $(0.0077)$ & $(0.0082)$ \\
& $-0.0038^{* * *}$ & $-0.0033^{* * *}$ & $-0.0048^{* * *}$ \\
ODA grants x low income & $(0.0012)$ & $(0.0013)$ & $(0.0013)$ \\
& $0.0030^{* * *}$ & $0.0023 *$ & $0.0028^{* *}$ \\
IMF conditionality & $(0.0012)$ & $(0.0013)$ & $(0.0014)$ \\
& & 0.0030 & 0.0010 \\
ODA grants x conditionality & & $(0.0076)$ & $(0.0075)$ \\
& & $0.0049 * *$ & $0.0057 * *$ \\
ODA grants x conditionality & & $(0.0026)$ & $(0.0025)$ \\
low income & & & \\
& & -0.0036 & -0.0036 \\
Adjusted R2 & & $(0.0028)$ & $(0.0027)$ \\
F-statistic & 0.928 & 0.930 & 0.935 \\
P-value & 775.5 & 704.3 & 662.1 \\
Observations & 0.000 & 0.000 & 0.000 \\
Number of countries & 1622 & 1578 & 1375 \\
\hline Notes: & 105 & 105 & 100 \\
\hline
\end{tabular}

Notes:

a) Dependent variable is the log of total tax revenue, relative to GDP. Full set of year dummies and control variables in all regressions. Standard errors, in parenthesis; $* * *(* *, *)$ indicate significance at $1(5,10)$ percent.

b) Column 3 includes the Inverse Mills ratio as additional control.

Results for the degree of reliance on aid are presented in Table 4. The degree of reliance on aid on tax revenue collection (Column 1) is investigated by interacting the ODA variable with a dummy variable for countries/years in which ODA was above 40 percent of total tax revenue (about 5 percent of GDP on average). The effect of aid on tax revenue collection among countries with moderate reliance on aid, as measured by the coefficient of the ODA variable without interaction, is negative but not statistically significant. For countries with high reliance on aid, however, an offsetting effect of aid on tax revenue collection emerges, with a negative and statistically significant coefficient for the interacted term in Column 1. The magnitude of the implied effect appears to be also larger than that obtained in Table 1.

In Column 2, the impact of revenue conditionality on the offsetting effect of aid on revenue is investigated. The estimated coefficient for the interaction between ODA and the revenue conditionality variable is positively and statistically significantly correlated with revenue collection. This latter effect appears to be similar among both countries with moderate and high reliance on aid, as the interacted term with the dummy for countries with high ODA is not statistically significant. Similar results are obtained in Column 3 once the Inverse-Mills ratio is included as additional control variable.

Interestingly, however, as suggested above, the offsetting effect of aid on tax revenue collection among countries with high ODA is not distinctively affecting low-income countries - those commonly benefiting the most from ODA - but rather middle-income countries instead. Table 4, Column 4 shows that the interacted variable for countries 
receiving high ODA in the low-income group is positively and statistically significantly correlated with revenue collection, suggesting that the negative effect of aid on tax revenue applies primarily to middle-income countries with high ODA reliance. Columns 5 and 6 confirm, in addition, that revenue conditionality has helped mitigate the offsetting effect of aid on revenue, and again this latter effect cannot be differentiated between low- and middleincome countries or those with moderate or high reliance on aid.

Table 4. ODA Grants and Revenue Conditionality on Tax Revenue by level of ODA

\begin{tabular}{|c|c|c|c|c|c|c|}
\hline & (1) & (2) & (3) & (4) & (5) & (6) \\
\hline Tax, lagged & $\begin{array}{l}0.9250 * * * \\
(0.0079)\end{array}$ & $\begin{array}{c}0.9280 * * * \\
(0.0079)\end{array}$ & $\begin{array}{c}0.9423 * * * \\
(0.0084)\end{array}$ & $\begin{array}{c}0.9235 * * * \\
(0.0079)\end{array}$ & $\begin{array}{c}0.9271 * * * \\
(0.0079)\end{array}$ & $\begin{array}{c}0.9418 * * * \\
(0.0084)\end{array}$ \\
\hline ODA grants & $\begin{array}{l}-0.0033 \\
(0.0022)\end{array}$ & $\begin{array}{l}-0.0024 \\
(0.0025)\end{array}$ & $\begin{array}{l}-0.0010 \\
(0.0025)\end{array}$ & $\begin{array}{l}-0.0033 \\
(0.0022)\end{array}$ & $\begin{array}{l}-0.0023 \\
(0.0025)\end{array}$ & $\begin{array}{l}-0.0014 \\
(0.0025)\end{array}$ \\
\hline ODA grants high & $\begin{array}{c}-0.0044 * * \\
(0.0020)\end{array}$ & $\begin{array}{l}-0.0034 * \\
(0.0023)\end{array}$ & $\begin{array}{l}-0.0034 \\
(0.0022)\end{array}$ & $\begin{array}{c}-0.0080 * * * \\
(0.0022)\end{array}$ & $\begin{array}{c}-0.0060 * * \\
(0.0026)\end{array}$ & $\begin{array}{c}-0.0062 * * \\
(0.0025)\end{array}$ \\
\hline $\begin{array}{l}\text { ODA grants high } \mathrm{x} \text { low } \\
\text { income }\end{array}$ & & & & $\begin{array}{l}0.0044 * * * \\
(0.0013)\end{array}$ & $\begin{array}{c}0.0031 * * \\
(0.0014)\end{array}$ & $\begin{array}{l}0.0034 * * \\
(0.0014)\end{array}$ \\
\hline IMF conditionality & & $\begin{array}{c}0.0012 \\
(0.0078)\end{array}$ & $\begin{array}{l}-0.0009 \\
(0.0076)\end{array}$ & & $\begin{array}{c}0.0006 \\
(0.0078)\end{array}$ & $\begin{array}{l}-0.0016 \\
(0.0076)\end{array}$ \\
\hline ODA grants $\mathrm{x}$ conditionality & & $\begin{array}{l}0.0046 * \\
(0.0033)\end{array}$ & $\begin{array}{l}0.0066 * * \\
(0.0033)\end{array}$ & & $\begin{array}{l}0.0052 * \\
(0.0035)\end{array}$ & $\begin{array}{c}0.0068 * * * \\
(0.0034)\end{array}$ \\
\hline $\begin{array}{l}\text { ODA grants high } \mathrm{x} \\
\text { conditionality }\end{array}$ & & $\begin{array}{l}-0.0030 \\
(0.0035)\end{array}$ & $\begin{array}{l}-0.0041 \\
(0.0034)\end{array}$ & & $\begin{array}{l}-0.0023 \\
(0.0038)\end{array}$ & $\begin{array}{l}-0.0041 \\
(0.0038)\end{array}$ \\
\hline $\begin{array}{l}\text { ODA grants high } \mathrm{x} \\
\text { conditionality } \mathrm{x} \text { low income }\end{array}$ & & & & & $\begin{array}{l}-0.0015 \\
(0.0030)\end{array}$ & $\begin{array}{l}-0.0004 \\
(0.0030)\end{array}$ \\
\hline Adjusted R2 & 0.928 & 0.930 & 0.925 & 0.928 & 0.930 & 0.935 \\
\hline F-statistic & 774.8 & 705.67 & 663.3 & 748.9 & 662.0 & 623.3 \\
\hline P-value & 0.000 & 0.000 & 0.000 & 0.000 & 0.000 & 0.000 \\
\hline Observations & 1622 & 1578 & 1375 & 1622 & 1578 & 1375 \\
\hline Number of countries & 105 & 105 & 100 & 105 & 105 & 100 \\
\hline
\end{tabular}

Notes:

a) Dependent variable is the log of total tax revenue, relative to GDP. Full set of year dummies and control variables in all regressions. Standard errors, in parenthesis; $* * *(* *, *)$ indicate significance at $1(5,10)$ percent.

b) Column 3 includes Inverse Mills ratio as additional control.

Finally, Table 5 presents the results for countries grouped on the basis of Transparency International's Corruption Perception Index, which is taken as a proxy for the strength of a country's institutions. For the analysis, the ODA variable is interacted with the corruption index, taking the value 0 (highest corruption) to 10 (lowest corruption). Results here are consistent with earlier findings in Benedek et al. (2014) in that aid offsets tax revenue particularly in countries with weak institutions (Columns 1). The interacted term of ODA and the corruption index is positively and statistically significantly associated with revenue collection, suggesting that for countries with stronger institutions (lower corruption), the offsetting effect of aid on revenue turns less significant. 
Similarly, revenue conditionality helps compensate for the negative effect of aid on tax revenue only in the presence of strong institutions. Column 2 shows a positive and statistically significant coefficient for the interacted term between ODA and revenue conditionality only for countries with low levels of corruption. This result is almost identical once the Inverse-Mills ratio is included as an additional control variable. This result is consistent with Montinola (2010) who finds that aid conditionality only promotes fiscal reform in more democratic countries.

Table 5. ODA Grants and IMF Revenue Conditionality on Total Tax Revenue by Quality of Institutions

\begin{tabular}{lccc}
\hline & $(1)$ & $(2)$ & $(3)$ \\
\hline Tax, lagged & $0.9253^{* * *}$ & $0.9305 * * *$ & $0.9477 * * *$ \\
ODA grants & $(0.0013)$ & $(0.0083)$ & $(0.0090)$ \\
ODA grants x strong institutions & $-0.0037 * * *$ & -0.0012 & -0.0022 \\
& $(0.0013)$ & $(0.0015)$ & $(0.0016)$ \\
IMF conditionality & $0.0012^{* *}$ & 0.0001 & -0.0001 \\
& $(0.0005)$ & $(0.0006)$ & $(0.0007)$ \\
ODA grants x conditionality & & 0.0043 & 0.0014 \\
& & $(0.0079)$ & $(0.0078)$ \\
ODA grants x conditionality x strong & & -0.0032 & -0.0031 \\
institutions & & $(0.0031)$ & $(0.0032)$ \\
& & $0.0019 *$ & $0.0023 *$ \\
& & $(0.0012)$ & $(0.0012)$ \\
Adjusted R2 & & & \\
F-statistic & & 0.930 & 0.935 \\
P-value & 688.5 & 644.5 & 580.4 \\
Observations & 0.000 & 0.000 & 0.000 \\
Number of countries & 1440 & 1401 & 1206 \\
\hline Notes: & 100 & 100 & 95 \\
\hline
\end{tabular}

Notes:

a) Dependent variable is the log of total tax revenue, relative to GDP. Full set of year dummies and control variables in all regressions. Standard errors, in parenthesis; $* * *(* *, *)$ indicate significance at $1(5,10)$ percent.

b) Column 3 includes Inverse Mills ratio as additional control.

\section{Concluding Remarks}

There is a long standing debate in the literature on the impact of aid on tax performance of aid-receiving countries. More recently, evidence has emerged to suggest that the observed offsetting effect of aid on tax revenues has weakened. This has led scholars to speculate about the factors behind this development. One plausible factor noted in the literature is the role of conditionality, as it is the case with revenue conditionality in IMF-supported programs; it has been argued that the commitment by countries to strengthen tax policy and administration as part of the overall reform program has fully or partially offset the disincentives to mobilize domestic revenues against the background of concessional inflows 
from abroad. This paper presented evidence from 111 low-and middle-income countries covering 1993-2012 to indicate that this is indeed the case. The impact of conditionality is strong in countries where aid dependence is high and where institutions are strong, suggesting that revenue conditionality cannot substitute for weak institutions in mitigating the negative effect of aid on tax revenue collection.

The paper makes another notable contribution by using two different tax databases to support its results. To our knowledge, this is the first such study that systematically deploys data compiled by two different agencies to show that in the absence of revenue conditionality, there would likely be a stronger negative effect of aid on tax collection, particularly from taxes on goods and services. 


\section{APPENDIX}

The countries in the sample are the following ${ }^{20}$ :

Low-income countries: Benin, Burkina Faso, Burundi, Cambodia*, Central African Rep., Chad, Comoros, Congo, Dem. Rep. of, Eritrea, Ethiopia, The Gambia, Ghana, Guinea, Guinea-Bissau*, Kenya, Kyrgyz Republic, Lao People's Democratic Republic, Liberia, Madagascar, Malawi, Mali, Mauritania, Mozambique, Nepal, Niger, Rwanda, Sierra Leone, Tajikistan, Tanzania, Togo, Uganda, Zambia, Zimbabwe*.

Middle-income countries: Albania, Algeria, Angola, Antigua and Barbuda, Argentina, Armenia, Azerbaijan, Belarus, Belize, Bolivia, Bosnia and Herzegovina, Botswana, Brazil, Cameroon, Cabo Verde, Chile, China, P.R.: Mainland, Colombia, Republic of Congo, Costa Rica, Côte d'Ivoire, Djibouti, Dominica, Dominican Republic, Ecuador, Egypt, El Salvador, Fiji*, Gabon, Georgia, Grenada, Guatemala, Guyana, Honduras, Indonesia, Jamaica, Jordan, Kazakhstan, Lebanon, Lesotho, Libya, Malaysia*, Maldives, Mauritius, Mexico, Moldova, Morocco, Namibia, Nicaragua, Nigeria, Pakistan, Panama, Papua New Guinea, Paraguay, Peru, Philippines, Samoa*, Senegal, Seychelles, South Africa, St. Kitts and Nevis, St. Lucia, St. Vincent and the Grenadines, Sudan, Suriname, Swaziland, Syrian Arab Republic, São Tomé and Príncipe, Thailand, Tonga, Tunisia, Turkey, Ukraine, Uruguay, Uzbekistan, Vanuatu*, Rep. Bol. Venezuela, Vietnam**, Republic of Yemen.

Data on total tax revenue, taxes on goods and services, income tax revenue, and trade tax revenue are taken from two different databases as discussed in Section II.A. The IMF's Fiscal Affairs Department revenue database, in its latest edition, takes tax revenue data from three different sources: the IMF's Government Financial Statistics (GFS) database, the IMF's World Economic Outlook (WEO) database, and the Organization for Economic Co-operation and Development (OECD) Revenue Statistics in Latin America database, relative to GDP. To ensure consistency, only one source is used for a given tax series/country over the sample period. The dataset is available at https://www.imf.org/external $/ \mathrm{np} / \mathrm{sec} / \mathrm{pr} / 2015 / \mathrm{pr} 15374$.htm. The International Centre for Tax and Development (ICTD) revenue dataset takes data from several sources, including those mentioned above, plus data compiled from available IMF article IV reports. A detailed explanation of the different data sources, construction of the database, and limitations and challenges is available in Prichard, Cobham, and Goodall (2014). For the purpose of our analysis — following the authors' suggestion — we have excluded observations that are flagged for potential inconsistency, analytical comparability, or issues related to natural resource taxation.

\footnotetext{
${ }^{20}$ If the country is denoted with $(*)$ means data is only available for the ICTD database; and $\left({ }^{* *}\right)$ means data is only available for the IMF's FAD database.
} 
Data on Official Development Assistance (ODA) in the form of grants were collected from the OECD's Development Assistance Committee database. It consists of disbursements of grants by official agencies of the members of the Development Assistance Committee (DAC), by multilateral institutions, and by non-DAC countries to promote economic development and welfare in countries and territories in the DAC list of ODA recipients. The full detail on how data is compiled and methodology can be found in http://www.oecd.org/dac/.

Data for the construction of the dummy variables on IMF-supported programs as well as on revenue conditionality are taken from the IMF's Monitoring of Fund Arrangements (MONA) Database. Among the economic descriptors for conditionality in the MONA database, considered in this paper are those related to revenue conditionality, which are: revenue measures and revenue administration. In addition, only revenue conditionality that was met at the time of the test date is considered. For IMF-supported programs, the dummy takes the value 1 if the country has a program in the year $t$ and zero otherwise. The starting year of a program is defined as the year in which it was approved. The end year is the year in which the program expired. For revenue conditionality, the dummy takes the value 1 if the country has a program that contains revenue conditionality for a given tax in year $t$ and zero otherwise. For the analysis on individual taxes, specific revenue conditionality related to each type of taxes was considered. For taxes on goods and services, conditionality was taken referring to value-added and excise taxes. For income taxes, conditionality on personal income tax as well as on tax on company profits was considered. For intensity of revenue conditionality, a variable is constructed taking the actual number of revenue conditions in IMF programs for each country/year divided by the total number of conditions in IMF programs for each country/year, respectively. The data for this variable are also taken from the IMF's MONA database.

Share of agriculture in aggregate value added and share of industry in value added are taken from the World Bank's World Development Indicators (WDI) database. Trade Openness is calculated as imports plus exports in percent of GDP, taken from the IMF's International Financial Statistics (IFS) database. Per capita GDP is calculated in constant (2000) U.S. dollars, taken from the WDI database, expressed in logs. Inflation is the annual change in the $\mathrm{CPI}$, taken from the IFS database. International reserves, nominal foreign exchange rate to the US dollar is taken from the IMF's IFS database. The overall fiscal balance, in percent of GDP, is taken from the WDI database. Finally, Transparency International's Corruption Perception index, which measures the level of corruption in 152 countries, transformed to take the value 0 (high corruption) to 10 (low corruption). This indicator is available online at www.qog.pol.gu.se, from Dahlberg et al. (2015). Table A1 summarizes the data. 
Appendix Table A1. Summary statistics

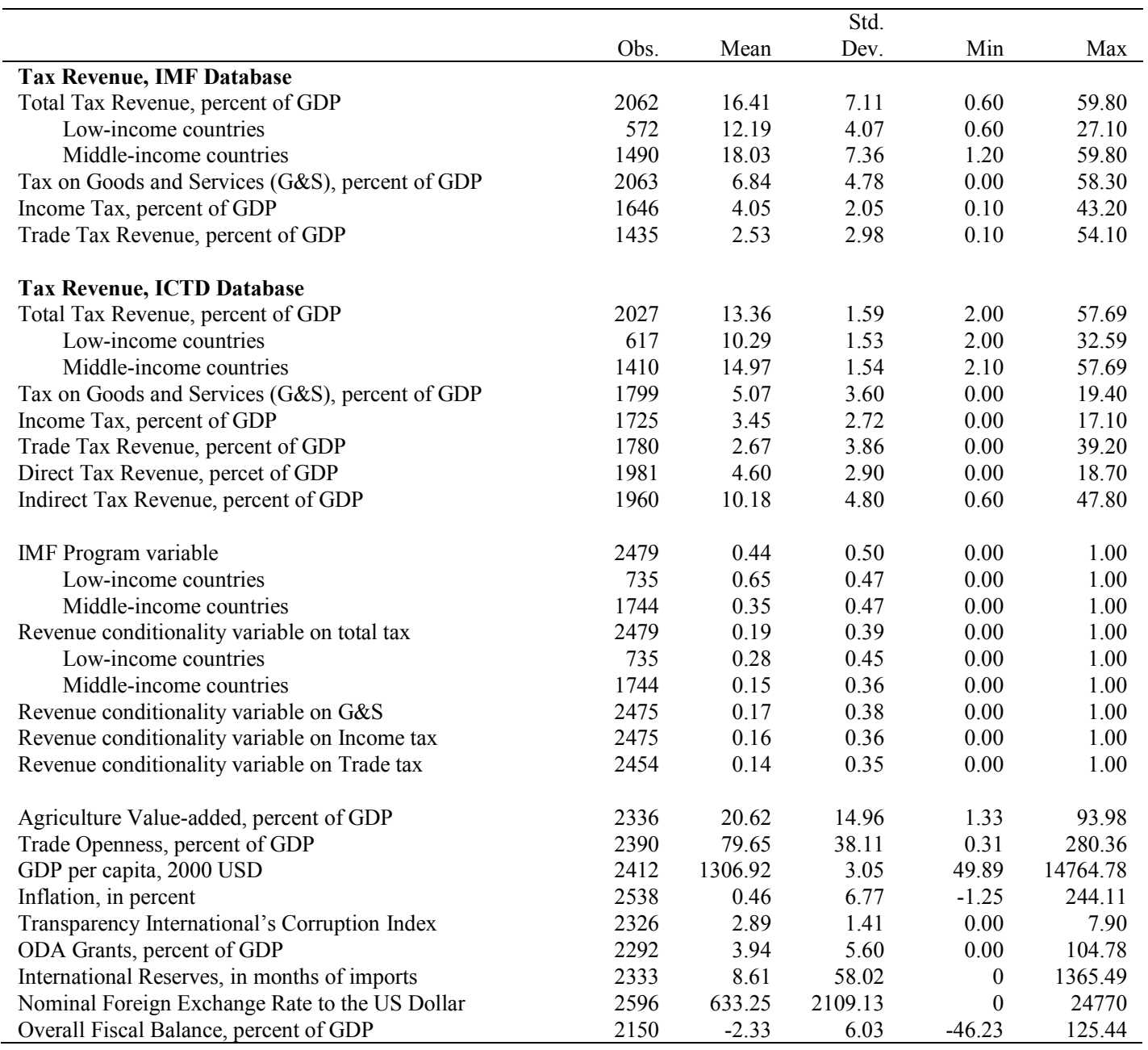

\section{Appendix Table A2. Result of Probit Regression to Generate Inverse Mills Ratio}

\begin{tabular}{ll}
\hline Overall fiscal balance, lagged & 0.008 \\
& $(0.005)$ \\
International reserves, lagged & $-0.058^{* * *}$ \\
& $(0.008)$ \\
Exchange rate, lagged & $0.001^{* * *}$ \\
& $(0.000)$ \\
Constant & $0.138^{* * *}$ \\
& $(0.053)$ \\
Observations & 1971 \\
R-squared & 0.04 \\
\hline Notes: & \\
a/ Dependent variable is IMF Program. Standard errors, in \\
parenthesis; $* * *(* * *)$ indicate significance at $1(5,10)$ \\
percent.
\end{tabular}




\section{Appendix Table A3. Intensity of Revenue Conditionality (OLS and system-GMM)}

\begin{tabular}{|c|c|c|c|c|c|c|}
\hline & $(1)$ & $(2)$ & (3) & $(4)$ & $(5)$ & $(6)$ \\
\hline & & IMF & & & ICTD & \\
\hline \multicolumn{7}{|l|}{ A) $O L S$} \\
\hline Tax, lagged & $\begin{array}{c}0.9283 * * * \\
(0.0077)\end{array}$ & $\begin{array}{c}0.9286 * * * \\
(0.0077)\end{array}$ & $\begin{array}{c}0.9422 * * * \\
(0.0081)\end{array}$ & $\begin{array}{c}0.9269 * * * \\
(0.0079)\end{array}$ & $\begin{array}{c}0.9269 * * * \\
(0.0079)\end{array}$ & $\begin{array}{c}0.9497 * * * \\
(0.0080)\end{array}$ \\
\hline ODA grants & $\begin{array}{c}-0.0013 * * \\
(0.0006)\end{array}$ & $\begin{array}{c}-0.0017 * * * \\
(0.0006)\end{array}$ & $\begin{array}{c}-0.0025^{* * *} \\
(0.0008)\end{array}$ & $\begin{array}{l}-0.0009^{*} \\
(0.0005)\end{array}$ & $\begin{array}{l}-0.0010^{*} \\
(0.0006)\end{array}$ & $\begin{array}{c}-0.0020 * * * \\
(0.0008)\end{array}$ \\
\hline IMF conditionality & & $\begin{array}{c}0.0077 \\
(0.0235)\end{array}$ & $\begin{array}{c}0.0068 \\
(0.0223)\end{array}$ & & $\begin{array}{c}0.0317 \\
(0.0217)\end{array}$ & $\begin{array}{c}0.0126 \\
(0.0217)\end{array}$ \\
\hline $\begin{array}{l}\text { ODA grants } \mathrm{x} \\
\text { conditionality }\end{array}$ & & $\begin{array}{c}0.0065 * * \\
(0.0032)\end{array}$ & $\begin{array}{l}0.0066 * \\
(0.0036)\end{array}$ & & $\begin{array}{c}0.0022 \\
(0.0027\end{array}$ & $\begin{array}{l}0.0054 * \\
(0.0033)\end{array}$ \\
\hline $\begin{array}{l}\text { Adjusted R2 } \\
\text { F-statistic } \\
\text { P-value } \\
\text { Observations } \\
\text { Number of countries }\end{array}$ & $\begin{array}{c}0.927 \\
802.5 \\
0.000 \\
1622 \\
105\end{array}$ & $\begin{array}{c}0.928 \\
746.7 \\
0.000 \\
1622 \\
105\end{array}$ & $\begin{array}{c}0.934 \\
694.1 \\
0.000 \\
1404 \\
100\end{array}$ & $\begin{array}{c}0.934 \\
989.9 \\
0.000 \\
1663 \\
111\end{array}$ & $\begin{array}{c}0.934 \\
914.7 \\
0.000 \\
1663 \\
111\end{array}$ & $\begin{array}{c}0.944 \\
817.7 \\
0.000 \\
1296 \\
104\end{array}$ \\
\hline \multicolumn{7}{|l|}{ B) System-GMM } \\
\hline Tax, lagged & $\begin{array}{c}0.0226 \\
(0.0966)\end{array}$ & $\begin{array}{c}0.0022 \\
(0.0369)\end{array}$ & & $\begin{array}{c}0.1022 * * * \\
(0.0259)\end{array}$ & $\begin{array}{c}0.0946 * * * \\
(0.0284)\end{array}$ & \\
\hline ODA grants & $\begin{array}{c}-0.0104 * * * \\
(0.0040)\end{array}$ & $\begin{array}{c}-0.0101 * * * \\
(0.0016)\end{array}$ & & $\begin{array}{c}-0.0034 * * * \\
(0.0011)\end{array}$ & $\begin{array}{c}-0.0027 * * \\
(0.0012)\end{array}$ & \\
\hline IMF conditionality & & $\begin{array}{c}0.3535 * * * \\
(0.1252)\end{array}$ & & & $\begin{array}{c}0.3679 * * * \\
(0.0973)\end{array}$ & \\
\hline $\begin{array}{l}\text { ODA grants } \mathrm{x} \\
\text { conditionality }\end{array}$ & & $\begin{array}{l}0.0202 * \\
(0.0119)\end{array}$ & & & $\begin{array}{l}0.0126 * \\
(0.0070)\end{array}$ & \\
\hline M1 (p value) & 0.000 & 0.005 & & 0.039 & 0.003 & \\
\hline M2 (p value) & 0.655 & 0.408 & & 0.160 & 0.349 & \\
\hline Over-identification & & & & & & \\
\hline Hansen $\mathrm{p}$ value & 0.655 & 0.641 & & 0.141 & 0.265 & \\
\hline Number of instruments & 81 & 81 & & 81 & 81 & \\
\hline
\end{tabular}

Notes:

a) Dependent variable is the log of total tax revenue, relative to GDP. Full set of year dummies and control variables in all regressions. Standard errors, in parenthesis; $* * *(* *, *)$ indicate significance at $1(5,10)$ percent.

b) Column 3 and 6 includes Inverse Mills ratio as additional control in OLS.

c/ System-GMM is one step, with instruments (collapsed) based on first lag of differences in tax, international reserves (in months of imports, lagged), the exchange rate to the US dollar (lagged), and the overall fiscal balance (in percent of GDP, lagged), and second lags of their levels in the differenced equation. The choice of the instruments follows Clements, Gupta, and Nozaki (2012) in dealing with potential selection-bias problem. 
Appendix Table A4. Using Lags of 5-year Averages of Explanatory Variables

\begin{tabular}{lccc}
\hline & $(1)$ & $(2)$ & $(3)$ \\
\hline Tax, lagged & $0.9471 * * *$ & $0.9468^{* * *}$ & $0.9706^{* * *}$ \\
& $(0.0086)$ & $(0.0086)$ & $(0.0089)$ \\
ODA grants, 5-yr lag & $-0.0019 * *$ & $-0.0026^{* * *}$ & $-0.0025^{* *}$ \\
& $(0.0008)$ & $(0.0009)$ & $(0.0010)$ \\
IMF conditionality, 5-yr lag & & -0.0065 & -0.0076 \\
ODA grants x conditionality, & & $(0.0087)$ & $(0.0088)$ \\
5-yr lag & & $0.0043 * *$ & $0.0040 * *$ \\
& & $(0.0020)$ & $(0.0021)$ \\
Adjusted R2 & 0.928 & 0.928 & 0.934 \\
F-statistic & 875.4 & 792.7 & 765.4 \\
P-value & 0.000 & 0.000 & 0.000 \\
Observations & 1275 & 1274 & 1188 \\
Number of countries & 106 & 106 & 101 \\
\hline
\end{tabular}

Notes:

a) Dependent variable is the log of total tax revenue, relative to GDP. Full set of year dummies and control variables in all regressions. Standard errors, in parenthesis; $* * *(* * *)$ indicate significance at $1(5,10)$ percent.

b) Explanatory variables are 5-year averages, 5 year lagged, meaning, for example, that the impact of tax revenue in year 2010 is explained by the average of ODA grants in years 2001-2005.

c) Column 3 includes Inverse Mills ratio as additional control. 


\section{REFERENCES}

Auriol, E., and M. Warlters, 2005, "Taxation base in developing countries," Journal of Public Economics, pp. 625-46.

Barro, R., and J. Lee, 2005, "IMF programs: who is chosen and what are the effects?" Journal of Monetary Economics 52, pp. 1245-69.

Baunsgaard, T., and M. Keen, 2010, “Tax Revenue and (or?) Trade Liberalization," Journal of Public Economics 94(9-10), pp. 563-77.

Benedek, D., E. Crivelli, S. Gupta, and P. Muthoora, 2014, "Foreign Aid and Revenue: Still a Crowding-Out Effect? FinanzArchiv: Public Finance Analysis 70(1), pp. 67-96.

Bulir, A., and J. Hamann, 2001, "How Volatile and Unpredictable Are Aid Flows, and What Are the Policy Implications?” IMF Working Paper 01/167 (Washington: International Monetary Fund).

Carter, P., 2013, “Does Foreign Aid Displace Domestic Taxation?” Journal of Globalization and Development 4(1).

Clements, B., S. Gupta, and M. Nozaki, 2013, "What happens to social spending in IMFsupported programmes?” Applied Economics 45(28), pp. 4022-33.

Clist, P., and O. Morrissey, 2011, "Aid and Tax Revenue: Signs of a Positive Effect since the 1980s," Journal of International Development 23, pp.165-80.

Clist P., 2014, "Foreign Aid and Domestic Taxation: Multiple Sources, One Conclusion," ICTD Working Paper 20, (Washington: International Centre for Tax and Development).

Conway, P., 2003, "Endogenous IMF conditionality: Theoretical and empirical implications," mimeo, University of North Carolina, Chapel Hill.

Crivelli, E., and S. Gupta, 2016, "Does conditionality in IMF-supported programs promote revenue reform?" International Tax and Public Finance 23(3), pp. 550-79.

Dahlberg, S., S. Holmberg, B. Rothstein, F. Hartmann, and R. Svensson, 2015, “The Quality of Government Basic Dataset: Version Jan15," University of Gothenburg, The Quality of Government Institute. Available under: http://www.qog.pol.gu.se

Djankov, S., J. Montalvo, and M. Reynal-Querol, 2008, “The Curse of Aid," Journal of Economic Growth 13, pp. 169-194. 
Gambaro, L., J. Meyer-Spasche, and R. Ashikur, 2007, "Does Aid Decrease Tax Revenue in Developing Countries," London School of Economics, mimeo.

Ghura, D., 1998, “Tax Revenue in Sub-Saharan Africa: Effects of Economic Policies and Corruption," IMF Working Paper 98/135.

Gujarati, D., and D. Porter, 2009, “Basic Econometrics,” McGraw-Hill Irwin.

Gupta, S., B. Clements, A., Pivovarsky, and E. Tiongson, 2004, "Foreign Aid and Revenue Response: Does the Composition of Aid Matter?” In: Gupta, S., B. Clements, and G. Inchauste (eds), Helping Countries Develop: The Role of Fiscal Policy, International Monetary Fund, D.C.

Heckman, J., 1976, "The common structure of statistical models of truncation, sample selection and limited dependent variables and a simple estimator for such models," Annals of Economic and Social Measurement 5(4), pp. 475-492.

Heckman, J., 1979, “Sample Selection Bias as a Specification Error,” Econometrica 47(1), pp. 153-161.

Hudson, J., 2015, “Consequences of Aid Volatility for Macroeconomic Management and Aid Effectiveness," World Development 69, pp. 62-74.

International Monetary Fund, 2011, "Revenue Mobilization in Developing Countries," Available at: www.imf.org/external/np/pp/eng/2011/030811.pdf

Knoll, M., 2011, "Foreign Aid and Revenue Response: An Examination of Joint General Budget Support," Discussion Paper 2011/23, Freie Universitaet Berlin.

Lee, A., and K. Lee, 2014, "Fiscal Behavior of Aid Recipient Countries during the Millennium Era," Analysis of Development Policy and International Cooperation 1(1), Korea Development Institute.

Montinola, G., 2010, "When Does Aid Conditionality Work?" Studies in Comparative International Development 45 (3), pp. 358-382.

Morrissey, O., 2015, “Aid and Government Fiscal Behavior: Assessing Recent Evidence," World Development 69, pp. 98-105. 
Morrissey, O., W. Prichard, and S. Torrance, 2014, “Aid and Taxation: Exploring the Relationship Using New Data,” ICTD Working Paper 21 (Washington: International Centre for Tax and Development).

Moser, C., and J-E. Sturm, 2011, "Explaining IMF lending decisions after the Cold War," The Review of International Organizations 6, pp. 307-40.

Prichard, W., A. Cobham, and A. Goodall, 2014, "The ICTD Government Revenue Dataset," ICTD Working Paper 19, (Washington: International Centre for Tax and Development).

Remmer, K., 2004, "Does Foreign Aid Promote the Expansion of Government?," American Journal of Political Science 48, pp. 77-92.

Rodrik, D., 1998, "Why Do More Open Economies have Bigger Governments? Journal of Political Economy 106, pp. 997-1032.

Thornton, J., 2013, "Does foreign aid reduce tax revenue? Further Evidence," Applied Economics 46(4), pp. 359-73. 